\title{
invotec
}

The International Journal of Technical and Vocational Education

UPI JOURNAL

Available online at http://invotec.fptk.upi.edu

\section{Design Conseptual of Hybrid Project Based Learning- PEPPER in Computer Networking Learning}

\author{
R. Haryadi, A. G. Abdullah \\ Technical and Vocational Education Studies Program, Graduate School of Universitas Pendidikan Indonesia \\ JI. Dr. Setiabudhi 229 Bandung 40154, Jawa Barat, INDONESIA
}

ARTICLE INFO

Article history:

Received 15 May 2015

Received in revised form 22

August 2015

Accepted 13 November 2015

Available online 11 December

2015

Keywords:

Project-based learning

PEPPER model

Learning of computer network.

Corresponding author:

rudigaries@gmail.com

\author{
A B S T R A C T
}

Learning of vocational school learning should be able to prepare students who have qualified skills to fit the demands of the realistic activity of industry. Professional activities within the workplace should be integrated completed the learning process in the classroom, through pedagogical model design that facilitates learning in order to build students who have the ability to work in accordance with the demands from the industry. Development of model design has been done through collaboration models Projectbased learning and PEPPER model through a mix method research. This research resulted a pedagogical syntax of learning model's tools with characteristic's industrial standard, which quantitatively tested in learning of Computer Network, so that the application of this model can improve the presumption of vocational school quality through graduate's quality.

\section{Introduction}

Vocational education graduates are prepared to have the appropriate competence and be able to develop a professional attitude of related industry. One major goal of modern learning in vocational education is to combine the process of drilling students with the realistic activity on the job (Tanggaard, 2007). The fact that, graduates of vocational school have a high competitiveness for employment also earned a higher income than the job seeker high school graduates (Newhouse, et al., 2011). So that schools can shape students into graduates who have mastery of job competencies, needed a model for learning in vocational education can be a solution to facilitate learning at the same time early adaptation to the circumstances around the world of work (Rouvrais, et al., 2006). 
Problem-based learning ( $\mathrm{PjBL}$ ) is an approach to learning in the classroom designed to improve students' skills in investigative authentic problems (Blumenfeld, et al., 1991). The PjBL provides the demands of the students and teachers to deal with the complex learning process, challenging, task of carrying out an authentic project that requires resources and careful planning by the student (Laffey, et al., 1998). Limited resources had always been an important obstacle in the implementation of the PjBL (Harry Scarbrough, et al., 2004). Flexibility in project-based learning environment allows students to measure their capabilities, resources, and plan (Grant, et al., 2005).

Trend of labor market demand requires new graduates must be ready to carry out his job. So requires educational institutions to review the educational process of pedagogical standpoint that the learning process is focused on preparing students to have professional competence (Rouvrais, 2006). Perspective of learning in the school and learning in the workplace is very different, because the workplace learning is more informal and incidental (Tynjälä, 2008). This problem becomes very interesting to bring the learning process in the workplace into the classroom. The PjBL has been greatly tested approach in improving students' skills in designing projects and solving authentic problems (Lam, et al., 2010; Panasan, 2010; Tongsakul, et al., 2011; Bédard, et al., 2012). Learning in vocational education should also equip students to have professional competence of the workforce. Pedagogic process approach can be done by combining the principles of PjBL with learning approach that has the characteristics can condition the student to be ready to adapt and to have professional competence in the industry.

Institute of Technical Education (ITE) of Singapore has successfully implemented a learning model that creates a culture of continuous learning to create students ready to face global economic competition (Lou Shizhou and Chen Dan, 2007). This model guiding the process of learning guides, habituation and product formation process of learning. The development process on this model include stages Plan, Explore, Practice, Perform (PEPP) which will guide the teacher in organizing learning through collaborative activities (learning cycle) in building habituation consisting of Enquiry activities and Reflect. Results of applicability, will be learning the product obtained in the form of professional knowledge learning outcomes are documented and in-sharing (tangible product) and teachers who always used to improve the quality of learning (Leong, 2004). To apply them in the learning process of vocational education in Indonesia will conduct a conceptual model of pedagogy of learning PjBL design combined with PEPPER learning model.

\section{Reseach Method}

PjBL-PEPPER hybrid models developed in the form of research and development learning model, so that the research process consists of the stages of development and testing of a model, the research approach method uses a mixture (mix method), the research procedures for collecting, analyzing and combining quantitative research process and in a qualitative study to understand the problem (Levin, et al., 2013).

Design of research model used an exploratory sequential design, sequential process results of the first research method can be used to develop or inform the second method. This design is chosen with consideration that the process of developing a hybrid model required an investigation to establish the syntax of components which are then tested on the samples. The design of the research conducted is shown in Figure 1.

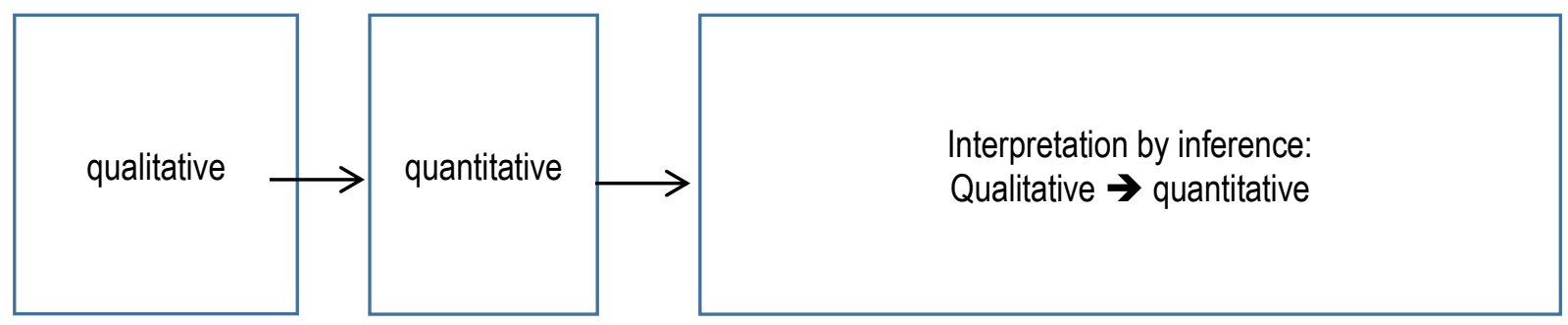

Figure 1. An Exploratory Sequential Design

Type of exploratory sequential design used in this research is the instrument development models, types have been selected on the application of the second model (quantitative) requires the implementation 
of instruments that is based on the character created based on qualitative findings, the design of this design is shown in Figure 2.

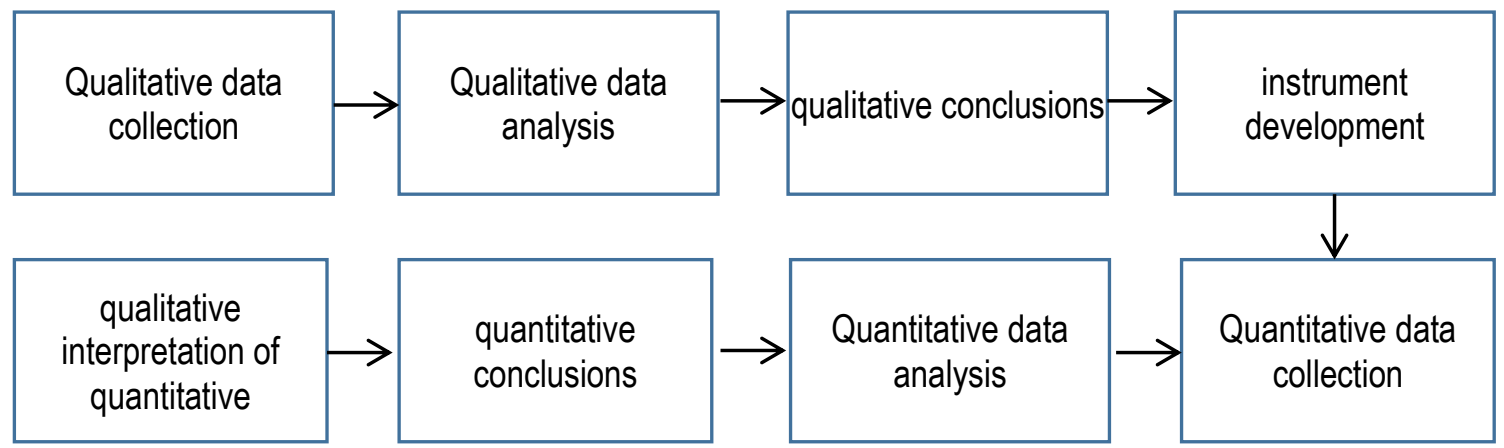

Figure 2. Sequential Exploratory Design : Instrument Development Models

First phase of the research used a qualitative approach with a qualitative descriptive design was intended to establish the facts, circumstances, phenomena, variables and circumstances that occurred while running the research and presenting what it is. Mean the application of the approach in this study is to develop a hybrid model syntax PjBL-PEPPER.

Second phase of the research used a quantitative approach using design: a quasi-experimental one group pre test and post test design, which is intended to determine whether or not the result of a treatment that is imposed on a group of subjects inquired, design for phase 2 study is shown in Figure 3 ,

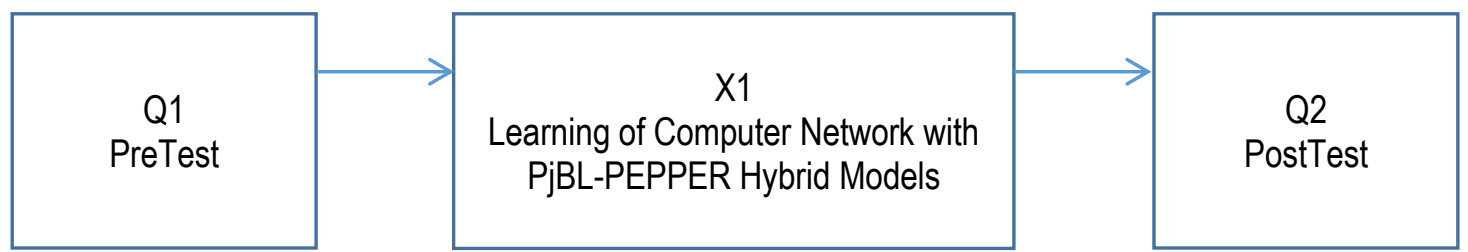

Figure 3. Research Design : One Group Pre Test and Post Test Design

Samples of the research are given pre-test (Q1), then the students will get a hybrid learning model PPEPPER in an effort to gain industrial competence on learning Computer Network (X1), then students are given a post-test the same as in the pre-test to determine learning outcomes in the form of an increase in student learning achievement (Q2). Participants of the research is Computer Network Engineering of Vocational High School Network consisting of 35 students and vocational teachers as peer observer. The sample selection of this study because the students carry out learning Computer Networks as an object of research.

Referring to the research design, the research procedure consists of the stages of model development, testing and data analyzing and conclusions, Figure 4 shows the research stage procedure which identified as the formulation of the problem in research. Phase of model development, covering the manufacture of product design in the form of the preparation of hybrid models drawn from an analysis of the model and the model PjBL- PEPPER, further design assessment by experts, to get the syntax validation of hybrid models. Phase of model testing to measure the effectiveness, efficiency and attractiveness of the design is done in the form of learning tools include document preparation task analysis, leraning Engagement Plan (LEP), teaching materials, instructional media, worksheets and reflection are used in learning Computer Network. The stage of data analysis and conclusion to know the difference of the two times measurement, by pre-test and post-test were escorting treatment of learning the successful use of the model is shown by the results of the evaluation of the student gain. 


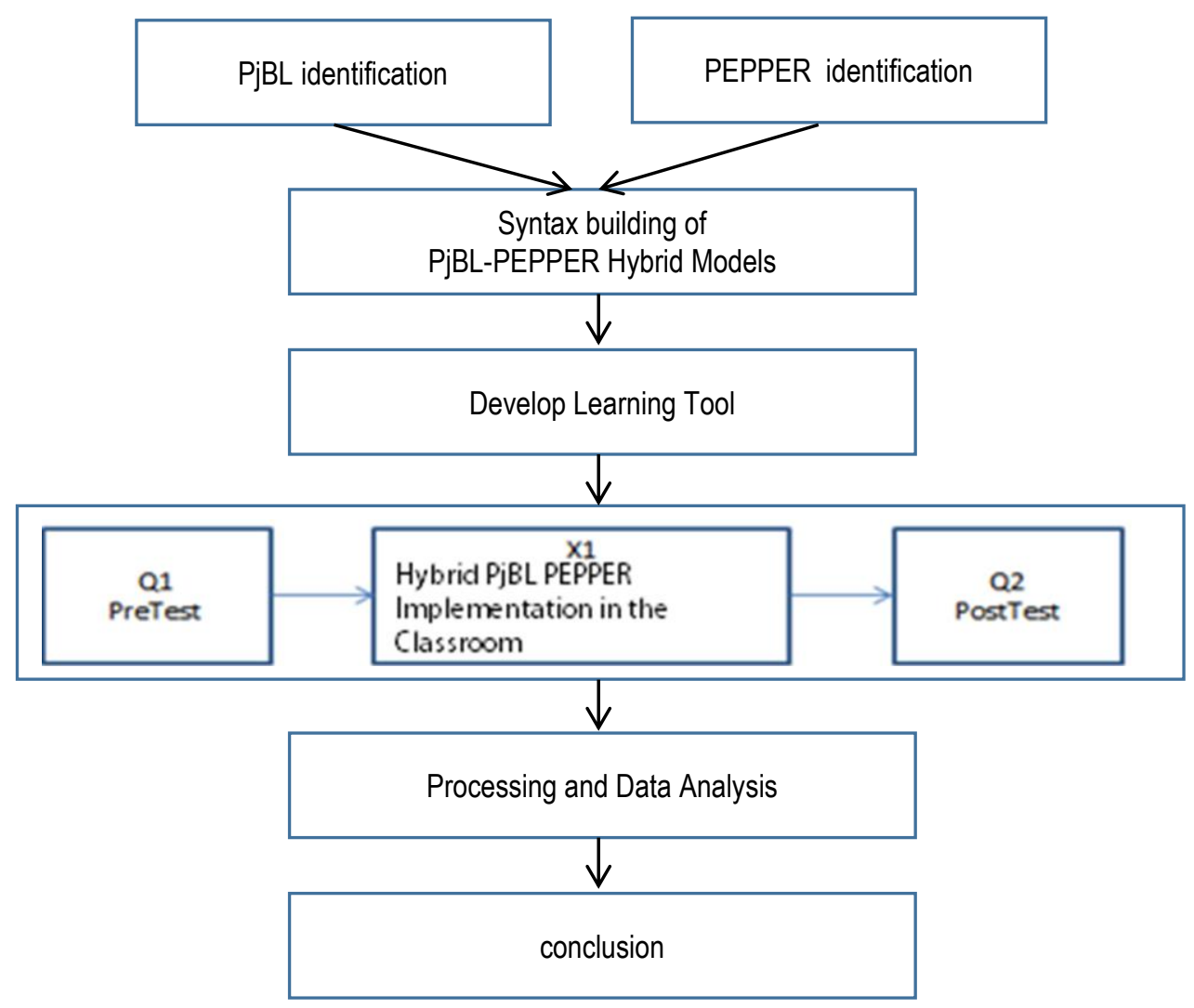

Figure 4. Research Procedure

Data processing has been done in order to find the value of the effective use of PjBL-PEPPER hybrid models in learning Computer Networks statistical calculations to test the effectiveness of PjBL -PEPPER hybrid models that do are: (1) Test the difference between two measurements, measurement with $T$ test when normally distributed data or Wilcoxon test when the data were not normally distributed. (2) Calculating the average gain of the acquisition of student achievement of the acquisition value of cognitive pre-test and post-test.

\section{Results and Discussion}

\section{The Syntax of PjBL-PEPPER Hybrid Model}

Syntax of PjBL-PEPPER hybrid model consisting of four steps of learning, namely (1) Orientation Competence (OKK), (2) Deepening Learning Materials (PMB), (3) Presentation of Work Competence (PKK) and Reflection. slice of origin model as a process of formation of the hybrid model are shown in Table 1

Table 1

The Sliced of PjBL and PEPPER models

\begin{tabular}{|c|c|c|}
\hline Project Based Learning & PEPPER & Hybrid PjBL-PEPPER \\
\hline $\begin{array}{l}\text { 1. Determination of } \\
\text { fundamental questions } \\
\text { 2. Designing project planning } \\
\text { 3. Develop project schedule }\end{array}$ & 1. Plan & $\begin{array}{l}\text { 1. Orientation Competence } \\
(\mathrm{OKK})\end{array}$ \\
\hline $\begin{array}{l}\text { 4. Monitoring of learners and } \\
\text { the progress of the project }\end{array}$ & $\begin{array}{l}\text { 2. Explore } \\
\text { 3. Practice }\end{array}$ & $\begin{array}{l}\text { 2. Deepening Learning } \\
\text { Materials (PMB) }\end{array}$ \\
\hline 5. Test results & 4. Perform & $\begin{array}{l}\text { 3. Presentation of Work } \\
\text { Competence (PKK) }\end{array}$ \\
\hline 6. Evaluate experience & $\begin{array}{l}\text { 5. Enquiry } \\
\text { 6. Reflect }\end{array}$ & 4. Reflection \\
\hline
\end{tabular}


After validation through expert-judgment regarding the composition of syntax, PjBL-PEPPER hybrid model described in Figure 5.

\begin{tabular}{|c|}
\hline 1. Orientation Competence (OKK) \\
\hline $\begin{array}{l}\text { orientation of the world of work and job description related knowledge and skills } \\
\text { that will be learned to aet the iob competence. }\end{array}$ \\
\hline$\sqrt{ }$ \\
\hline 2. Deepening Learning Materials (PMB) \\
\hline $\begin{array}{l}\text { Use a variety of methods and learning resources to dig in the development of } \\
\text { learning materials enrichment work as demanded competence }\end{array}$ \\
\hline$\Downarrow \boldsymbol{\Lambda}$ \\
\hline 3. Presentation of Work Competence (PKK) \\
\hline $\begin{array}{l}\text { Skills required by the employment of competence is shown through the fulfillment } \\
\text { of the skills that match the criteria of performance }\end{array}$ \\
\hline$\Downarrow$ \\
\hline 4. Reflection \\
\hline $\begin{array}{l}\text { Meanings of learning that have been made to the competence, the learning } \\
\text { process and the use of learning outcomes in the industrial standard. }\end{array}$ \\
\hline
\end{tabular}

Figure 5. Syntax of PjBL-PEPPER Hybrid Model

Details syntax PBL-PEPPER hybrid model, can be explained as follows:

1. Competence Work Orientation

- Identification of job competence (task analysis) in accordance with the competence of work / learning theme.

- Submission of the working scenario

- Submission of goals, objectives and target learning

- Exploring students' initial knowledge of the learning material.

- Giving stimulation and increase students' motivation

2. Deepening Learning Materials

- Deepening study materials with student-centered methods.

- Use a variety of learning resources

3. Presentation of Work Competence

- Presenting the learning objectives through performance work skills

- Obtain proof of concept through deepening

- Finding the necessary competence in the working world

- Documenting the learning experience experienced

4. Reflection

- Publishes a learning experience and work competence

- Inference and learning materials tailored to the competence of the workforce

- Giving feedback learning

- Reflection learning experience

Adoption of competence working on a hybrid model PjBL-PEPPER makes learning feel more real, it adds to students' motivation to learn competence fulfillment according to the demands of the industry. In the design of learning, a hybrid model PjBL -PEPPER emphasis on three things:

- Authentic / realistic learning, the role of the working world continues to affect every student activities. This role is felt by the students through instruction / learning guide through a scenario and conditioning work every step of learning that has always been associated with the situation in employment. 
- Integrated learning, presents a model of learning centered on student activities (SCL) on an integrated working procedures. Learning is directed to a description of work activity began preparations until the final stage of a job completed.

- Practical, instructional implemented with emphasis on practical activities to enrich students' job skills.

Each stage study on the hybrid model PjBL-PEPPER applied to the computer network has a goal of learning that can be used as indicators of the success of the learning with this model, ie:

1. Stages of work competence orientation (OKK), the students declared successful at this stage if the student has the ability to identify the implementation of learning material will do. Students have an overview of professional competence to be mastered Computer Network after he studied the study material.

2. Stages deepening the learning material $(\mathrm{PMB})$ at this stage the teacher to plan and determine the learning strategies so that students can achieve learning goals effectively and efficiently. Teachers provide stimulus and trying to increase students' motivation through various types of activities oriented to student activity, so an understanding of the basic knowledge and concepts Computer Networks discovered by the students.

3. Stages presentation of work competence (PKK) carried out in an effort to find a job competence in learning situations, it can be found peyelesaian work instructions and proof of concept through trials / practicum and observation. Students can find the application of the material learned in the implementation in the world of work through practical work and observation.

4. Reflection on the learning that has been done through inference and learning materials tailored to the competencies of the workforce and providing feedback as a reflection of the students' learning experience. Students can find out early gains and the weakness of the material results of their study on Computer Networks, making it useful for improving learning performance. Another benefit of this reflection is that the learning process in the future can be better organized.

\section{Learning Tools of PjBL-PEPPER Hybrid Model}

Learning process guided by arranged a number of learning tools with Hybrid characteristics PjBLPEPPER whose contents tailored to the learning material Computer Network. Learning device used consisted of:

1. Task Analysis, the decomposition of labor competence is the theme of learning. Diagram task analysis to study computer network addressing protocol is shown in Figure 6.
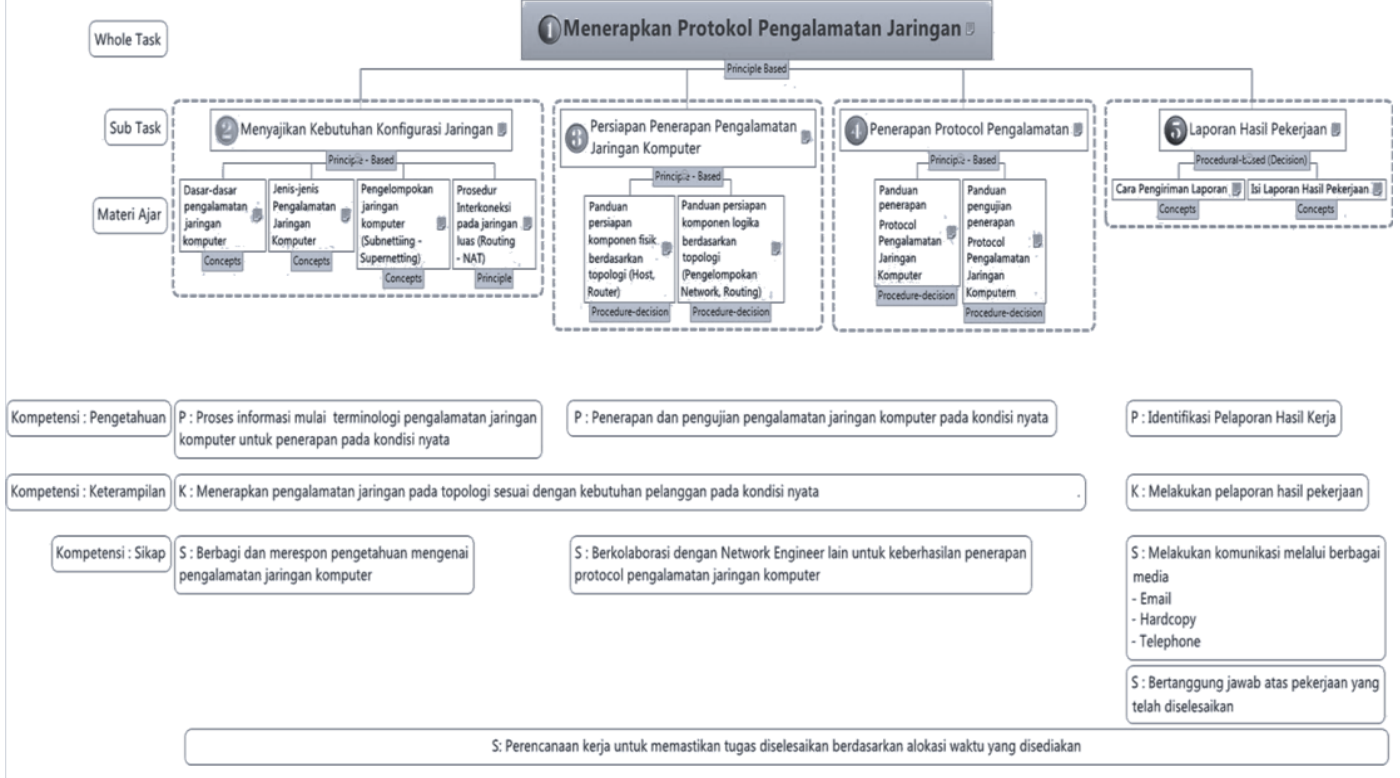

Figure 6. Task Analysis for Computer Networking Learning 
2. Learning Engagement Plan (LEP) with the characteristics of the industrial standard in the form of adaptation activities of the exposure scenario that guides learning work as a whole, the stages of work and work on details of activity teaching methods.

3. Subjects were arranged openly can be a reference in the learning that can come from scientific documents or of industrial standard that animates the character hybrid model PjBL-PEPPER.

4. Learning tools by using multimedia-based applications in order to guide the learning with industrial activity illustrations to the students.

5. Worksheet linking interaction of student learning, teachers and learning. This document is used as a measurement of student achievement of competence according to criteria of performance, because there is a form that shows the assessment of student achievement.

6. Reflection sheet is used as a guide to students' competency assessment and learning process. Reflection was conducted on the achievement of learning outcomes and learning processes are performed.

The use of hybrid model learning device PjBL-PEPPER very influential in the success of learning. For this study the role of the teacher useful as a guide for the achievement of learning targets, learning will be implemented effectively and efficiently. Effective because the target is achieved in a systematic study according to plan, efficient in the context of allocation of instructional time can be used well in achieving learning goals and achievement of student competency. For students learning the role of the device is a guide for learning the dilaksanakanya. (Levin, 2013).

Learning device used in the study by using a hybrid model PjBL -PEPPER are: Task Analysis, LEP, Instructional Materials, Media Education, Student Worksheet, Reflection Sheet.

1. Task Analysis

As a competence decomposition of work into a number of learning materials, task analysis on hybrid model PjBL -PEPPER used as a guide on the learning process of students. Through document analysis task of professional competence Computer Networks identified for learning so that learning is done is always oriented to the learning material utilization activities in the world of work.

Task analysis compiled must have the following criteria: (1) Complete, consisting of components includes the whole learning support tasks, subtasks, study materials, performance criteria, learning objectives, components of competence. (2) Informative, served through informed instructional design.(3) Guiding learning, through the presentation of infomasinya can be a reference of learning implementation.

\section{Learning Engagement Plan (LEP)}

LEP arranged in such a way to illustrate lessons. Adoption of the activities of the world of work is presented in each section on the LEP. On the identity of the LEP document, the adoption of the world of work contained in the working scenario. While on the adoption of workplace learning details visible on the implementation of the strategy / method of learning. At the stage of learning takes control of the hybrid model PjBL -PEPPER.

\section{Instructional Materials}

Teaching materials on learning should be adapted to the psychological character of learners. For vocational level, students are able to identify the learning material from various sources of learning. Through teaching materials which contain descriptions of materials, detailing activities guide students and teachers are expected to guide the activities going on good pedagogical interactions in achieving learning expectations, especially in goal-oriented learning to the demands of the job competencies.

\section{Learning Media}

Good use of instructional media will facilitate student learning through integrated information between the guides, materials and learning assignments on the learning media. With good planning through storyboard creation, will produce an effective learning media used in learning.

\section{Student Worksheet}

Learning activities carried out by using methods that are student centered learning. Student worksheet is used to measure the achievement of job competence in the learning process of students, so this worksheet to be one of the key success of the application of hybrid models. 


\section{Reflection Sheet}

Activities of reflection and feedback is needed in the implementation of learning because in addition to measure the achievement of learning materials, this activity can also provide feedback that can be processed into suggestions for improvements to the learning process at a later time. Required commitment and openness of learning facilitators when performing data processing reflection, this may be an evaluation for individuals and for the evaluation of the educational system / learning implemented.

\section{Application of PjBL-PEPPER Hybrid Model on Learning Computer Network}

Experimental PjBL-PEPPER hybrid model on Addressing Protocol learning applied to the learning of computer networks as one of learning Computer Networks implemented within six stage face-to-face. Objects observations were made on three activities: (1) Observation of PjBL-PEPPER hybrid model, (2) Calculation increase student achievement and (3) Testing the effectiveness of the implementation of the hybrid model PjBL-PEPPER.

1. Observation of learning activities keterlaksanaan hybrid model PJBL-PEPPER learning computer network addressing protocol. Such analysis in Table 2 and Table 3.

\section{Table 2}

Number of Learning Activities Meeting by Face to Face

\begin{tabular}{cccc}
\hline Stage & $\begin{array}{c}\text { Number of Learning } \\
\text { Activity }\end{array}$ & Applicable & Prosentation \\
\hline $\mathbf{1}$ & 6 & 6 & $100 \%$ \\
$\mathbf{2}$ & 5 & 5 & $100 \%$ \\
$\mathbf{3}$ & 5 & 4 & $80 \%$ \\
$\mathbf{4}$ & 6 & 6 & $100 \%$ \\
$\mathbf{5}$ & 3 & 3 & $100 \%$ \\
$\mathbf{6}$ & 4 & 4 & $100 \%$ \\
\hline Total & 29 & 28 & \\
\hline
\end{tabular}

Table 3

Number of Learning Activities Meeting by PjBL-PEPPER Hybrod Models

\begin{tabular}{lccc}
\hline \multicolumn{1}{c}{ Syntax } & $\begin{array}{c}\text { Number of } \\
\text { Learning } \\
\text { Activity }\end{array}$ & Applicable & Prosentation \\
\hline $\begin{array}{l}\text { Competence Work Orientation } \\
\text { Deepening Learning Materials } \\
\begin{array}{l}\text { Presentation of Work } \\
\text { Competence }\end{array}\end{array}$ & 4 & 4 & $100 \%$ \\
$\begin{array}{l}\text { Reflection } \\
\text { Refleksi }\end{array}$ & 11 & 11 & $100 \%$ \\
& 4 & 9 & $90 \%$ \\
\hline$\quad$ Total & 29 & 4 & $100 \%$ \\
\hline
\end{tabular}

2. Calculation to get gain value of student learning outcomes for implementation Test Pre and Post test of each student obtained from the calculation using the formula:

$$
\text { Gain }=\frac{(\text { Post Test }- \text { Pre Test })}{(\text { Max.Score }- \text { Pre Test })}
$$

From the results of all students gain calculation, obtained an average gain of 0.57 . Score shows that the students gain valuable medium because it is in the range between $0,3-0.7$, so it can be said to be a hybrid model PBL-PEPPER effective enough to be applied to study Computer Networks.

3. The statistical calculation to obtain the success of the learning is done through a test measuring the difference twice pretest and posttest. Through testing Wilcoxon signed rank test (Wilcoxon pair test 
match) showed statistical measurements shown in Table 6 to Table 8 . Table 6 shows the test results of descriptive statistics.

Table 6

Descriptive statistics

\begin{tabular}{cccccc}
\hline & N & Mean & Std. & Minimum & Maximum \\
\hline Pre & 3 & 47,740 & 18,4687 & 15,4 & 84,7 \\
Pos & 3 & 78,32 & 13,78 & 46,20 & 100,00 \\
\hline
\end{tabular}

From Table 7 obtained 31 students scored postest> pre-test, and 4 students scored a pre-test value = post test. it can be said that most of the students were able to get the results of learning with hybrid models.

Table 7

Table Rank Details Value Comparison Test Pre and Post Test

\begin{tabular}{llcrr}
\hline & N & \multicolumn{1}{c}{$\begin{array}{c}\text { Mean } \\
\text { Rank }\end{array}$} & \multicolumn{2}{c}{$\begin{array}{l}\text { Sum of } \\
\text { Ranks }\end{array}$} \\
\hline Post - & Negative & $0^{\mathrm{a}}$ &, 00 &, 00 \\
Pre & $\begin{array}{l}\text { Ranks } \\
\text { Positive }\end{array}$ & $31^{\mathrm{b}}$ & 16,00 & 496,00 \\
& Ranks & & & \\
& Ties & $4^{\mathrm{c}}$ & & \\
& Total & 35 & & \\
&
\end{tabular}

a. Post $<$ Pre ; b. Post $>$ Pre ; c. Post $=$ Pre

The end result of this test is shown in Table 8, which shows the statistics of the test are tested, such as the $Z$ value and significance.

Table 8

Test of Statistics

\begin{tabular}{lr}
\hline & Post - Pre \\
\hline Z & $-4,874^{\mathrm{b}}$ \\
Asymp. Sig. (2-tailed) &, 000 \\
\hline a. Wilcoxon Signed Ranks Test \\
\multicolumn{2}{l}{ b. Based on negative ranks. }
\end{tabular}

From these test results obtained two differences: The value of the acquisition posttest> pretest, shows student achievement after treatment experienced better conditions, and Value of significance $<0.05$, showed no significant difference for student achievement before and after treatment. From the results of this test showed that that the implementation of the hybrid model of PjBL-PEPPER effectively to improve student achievement in learning Computer Network.

In the tradition of human resource development, the values of competence a worker can be fostered through education programs, development or training. The training program was organized as a unified way that is oriented to the demands of the current job, with an emphasis on the development of skills, knowledge and abilities (SKA). A worker who is able to achieve the most significant SKA will be able to improve their competence. This increased competency expected to be used to meet the standards of behavior in the system and work processes are applied. (Brooksbank, 1995)

Application of hybrid model of PjBL-PEPPER pedagogy in learning Computer Networks has contributed to the internalization of professional competence by students from the learning begins. At the beginning of learning when teachers convey information and picture material implementation Computer Network working scenario, students will begin to make the orientation of professional competence would he have in a work activity in the field of Computer Networks.

In theory deepening Computer Networking student uses a variety of sources through a variety of learning methods to strengthen professional skills with concepts and procedures accordingly. As an 
adaptation of her work, mastery of the concepts and procedures is corroborated by laboratory and real-world observations in the form of work activity that are integrated in the learning material as do the installation and configuration of the operating system that is tailored to the real needs and other appropriate activities.

Professional capability student performance measured through tests covering the whole work as described in the working scenario that comes with the process of reflection on the competence of the students, so that students have the adaptability and the ability to contribute significantly to the activities of the working world in the field of Computer Networks.

\section{Conclusion}

Research development of a hybrid model PjBL-PEPPER addressing protocol applied to the learning of computer networks generate some conclusions, including: Syntax of PjBL -PEPPER hybrid model presents a series of pedagogical activities that lead to learning can produce professional competence in learners, where each learning activity is done with the world of work-oriented activities. The devices used in the application of learning PjBL-PEPPER hybrid model pedagogical consists of a number of documents that have the characteristics of a standard integration work in guiding the students' learning in order to generate competence in accordance with the demands of work competence. Learning the material addressing protocol computer network using PjBL-PEPPER hybrid model pedagogical can facilitate learning for the achievement of learning and competence fulfillment of work as one of betuk adaptation of students in the work environment in accordance with the vocational field chosen, so the use of this hybrid model is considered sufficient effective for use in vocational learning material oriented to job competence.

\section{References}

Bédard, D., Lison, C., Dalle, D., Côté, D., \& Boutin, N. (2012). Problem-based and Project-based Learning in Engineering and Medicine: Determinants of Students' Engagement and Persistance. Interdisciplinary Journal of Problem-Based Learning, 6(2), 8-22. http://doi.org/10.7771/1541-5015.1355

Blumenfeld, P., Soloway, E., Marx, R., Krajcik, J., Guzdial, M., \& Palincsar, A. (1991). Motivating ProjectBased Learning: Sustaining the Doing, Supporting the Learning. Educational Psychologist. http://doi.org/10.1207/s15326985ep2603\&4_8

Brooksbank, J. (1995). Competency based training. The British Journal of Theatre Nursing: NATNews : The Official Journal of the National Association of Theatre Nurses.

Grant, M. M., \& Branch, R. M. (2005). Project-Based Learning In a Middle School : Tracing Abilities Through The Artifacts of Learning. Journal of Research on Technology in Education, 38(1), 65-99.

Harry Scarbrough, Jacky Swan, Stéphane Laurent, Mike Bresnen, L. E. and S. N. (2004). Project-based learning and the role of learning boundaries. Organization Studies, 25(June 2015), 1579-1599. http://doi.org/10.1177/0170840604048001

Laffey, J., Tupper, T., Musser, D., \& Wedman, J. (1998). A computer-mediated support system for projectbased learning. Educational Technology Research and Development, 46(1), $73-86$. http://doi.org/10.1007/BF02299830

Lam, S. F., Cheng, R. W. Y., \& Choy, H. C. (2010). School support and teacher motivation to implement project-based learning. Learning and Instruction, 20(6), 487-497. http://doi.org/10.1016/j.learninstruc.2009.07.003

Leong, P. (2003). Thinking Teachers in the eXCELERATE 21 Revolution of the PS21 Movement. Innovation and Diversity, 1(ASIA PACIFIC CONFERENCE ON EDUCATION), 1-9.

Leong, P. (2004). Embarking on a Learning Journey: Developing the PEPP\&ER Framework for Action Research. International Reseacrh Conference on Vocational Education and Training, (Ministry of Education, Thailand, The Federation of Private Vocational Schools of Thailand \& UNESCO 13 -14 Aug 2004).

Levin, T., \& Levin, I. (2013). Evaluating the Pedagogical Potential of Hybrid Models. Jl. of Computer in Mathematics and Science Teaching, 32(3), 303-320. 
Lou Shizhou and Chen Dan. (n.d.). Study on the PEPP\&ER Model in the Institute of Technical Education of Singapore.

Newhouse, D., \& Suryadarma, D. (2011). The value of vocational education: High school type and labor market outcomes in Indonesia. World Bank Economic Review, 25(2), $296-322$. http://doi.org/10.1093/wber/lhr010

Panasan. (2010). Learning Outcomes of Project-Based and Inquiry-Based Learning Activities. Journal of Social Sciences, 6(2), 252-255. http://doi.org/10.3844/jssp.2010.252.255

Rouvrais, S., Ormrod, J., Landrac, G., Mallet, J., \& Gilliot, J. (2006). A mixed project-based learning framework : preparing and developing student competencies in a French Grande Ecole. European Journal of Engineering Education, 31(1), 83-93. http://doi.org/10.1080/03043790500429500

Tanggaard, L. (2007). Learning at trade vocational school and learning at work: boundary crossing in apprentices' everyday life. Journal of Education and Work, 20(5), 453-466. http://doi.org/10.1080/13639080701814414

Teng, S. K. (2008). Cyberlab, Remote Virtual Educational Laboratory. Singapore: Institute of Technical Education, Singapore.

Tongsakul, A., Jitgarun, K., \& Chaokumnerd, W. (2011). Empowering Students Through Project-Based Learning: Perceptions Of Instructors And Students In Vocational Education Institutes In Thailand. Journal of College Teaching \& Learning, 8(12), 19-33.

Tynjälä, P. (2008). Perspectives into learning at the workplace. Educational Research Review, 3(2), 130154. http://doi.org/10.1016/j.edurev.2007.12.001 